\title{
Non-Genomic Effects of Aldosterone on Intracellular Ion Regulation and Cell Function in the Heart
}

\author{
Hiroshi Satoh $^{1, *}$, Saori Matsui ${ }^{2}$ and Hideharu Hayashi ${ }^{1}$ \\ ${ }^{I}$ Division of Cardiology, Internal Medicine III, Hamamatsu University School of Medicine, and ${ }^{2}$ Department of Internal \\ Medicine, Kosai General Hospital, Japan
}

\begin{abstract}
Serum aldosterone levels are often elevated in patients with heart failure and are associated with poor clinical outcomes. Aldosterone can be produced in extra-adrenal tissues including the heart, and the local increase in aldosterone exerts deleterious effects on heart structure and function. Aldosterone has 2 types of effects on intracellular ion milieu and cellular function. One is the classical genomic effect in which aldosterone combines with the intracellular mineralocorticoid receptor, transfers to the nucleus, and stimulates synthesis of various proteins. Another is the non-genomic effect that expresses within minutes without synthesizing proteins. The non-genomic effects of aldosterone are less proved in the heart, but it has been shown that aldosterone rapidly activates $\mathrm{Na}^{+}$influxes via $\mathrm{Na}^{+}-\mathrm{K}^{+}-2 \mathrm{Cl}^{-}$co-transport and $\mathrm{Na}^{+} / \mathrm{H}^{+}$exchange, resulting in an increase in intracellular $\mathrm{Na}^{+}$concentration and intracellular alkalinization. These changes in intracellular ion milieu cause positive inotropy, cell swelling, and generation of reactive oxygen species. Thus, the nongenomic effects of aldosterone may contribute, in concert with the genomic effects, to cardiac hypertrophy, fibrosis, and remodeling. This review will discuss the experimental studies examining the mechanisms and physiological/pathophysiological relevance regarding the non-genomic effects of aldosterone in the heart.
\end{abstract}

Keywords: Aldosterone, non-genomic effect, ion concentration, cell volume, hypertrophy.

\section{INTRODUCTION}

The steroid hormone aldosterone is synthesized in the adrenal cortex in response to angiotensin II. The primary effect of aldosterone is to promote renal sodium absorption in exchange for potassium and to maintain electrolyte homeostasis and extra-cellular fluid volume.

Aldosterone levels are often elevated in patients with heart failure and are associated with poor clinical outcomes $[1,2]$. The Randomized Aldactone Evaluation Study for congestive heart failure (RALES) has shown that a mineralocorticoid receptor (MR) antagonist, spironolactone, decreases mortality in patients with congestive heart failure [3]. The Eplerenone Post-AMI Heart Failure Efficacy and Survival Study (EPHESUS) has also demonstrated a decreased mortality in patients with left ventricular dysfunction after myocardial infarction treated with an MR-specific antagonist, eplerenone [4]. In both studies, the MR antagonists improved clinical outcomes independently of the effects on blood pressure. The plasma concentration of aldosterone increases up to $0.1 \mu \mathrm{M}$ in patients with heart failure, and the level of aldosterone in the myocardium is much higher than that in plasma $[5,6]$. The rapid and direct effects of aldosterone on the heart are, therefore, considered to have significant clinical relevance and to be important as a therapeutic target for heart failure.

*Address correspondence to this author at the Division of Cardiology, Internal Medicine III, Hamamatsu University School of Medicine. 1-20-1, Handayama, Higashi-ku, Hamamatsu, 431-3192, Japan; Tel: +81-53-435-2267; Fax:+81-53-434-2910; E-mail: satoh36@hama-med.ac.jp
Now it is well known that aldosterone has 2 types of effects on intracellular ion milieu and cellular function. One is the classical genomic effect and the other is the non-genomic effect that expresses within minutes without synthesizing proteins $[7,8]$. The non-genomic effect of aldosterone was initially reported at 1964 in dog erythrocytes in which genomic mechanisms did not work because of the lack of nucleus [9]. There are several reports regarding the nongenomic effects of aldosterone in a variety of tissues including vascular endothelium [10], vascular smooth muscles [11], kidney cells [12], skin cells [13], bronchial epithelium [14], mononuclear leukocytes [15], and skeletal muscles [16]. In these tissues, aldosterone rapidly changed intracellular $\mathrm{Na}^{+}, \mathrm{Ca}^{2+}$ and $\mathrm{H}^{+}$concentrations $\left(\left[\mathrm{Na}^{+}\right]_{\mathrm{i}},\left[\mathrm{Ca}^{2+}\right]_{\mathrm{i}}\right.$, and $\left.\mathrm{pH}_{\mathrm{i}}\right)$ by modifying ion fluxes through sarcolemma and via intracellular $\mathrm{Ca}^{2+}$ stores.

For cardiac myocytes, there are many reports on the genomic effects of aldosterone including the increases in $\mathrm{Ca}^{2+}$ and $\mathrm{K}^{+}$currents, the expression of T-type $\mathrm{Ca}^{2+}$ channels, and the activation of $\mathrm{Na}^{+} / \mathrm{H}^{+}$exchange [17-19]. However, there are only a few reports on non-genomic effects of aldosterone, e.g. $\mathrm{Na}^{+}-\mathrm{K}^{+}-2 \mathrm{Cl}^{-}$co-transporter $(\mathrm{NKCCl})$ and $\mathrm{Na}^{+} / \mathrm{H}^{+}$ exchange. The aldosterone-induced modulation of these ion transporters can certainly affect intracellular ion regulation and cellular function. However, it is still undefined in cardiac tissues whether aldosterone actually alters intracellular ion concentrations, cell volume or myocardial contractility due to non-genomic effects.

This review discusses the non-genomic effects of aldosterone on cellular ion regulation, function, and physiologi$\mathrm{cal} /$ patho-physiological implications in cardiac myocytes. 


\section{GENOMIC AND NON-GENOMIC EFFECTS OF ALDOSTERONE}

Genomic effects of aldosterone imply the binding to its intracellular receptor and the translation of the ligandreceptor-complex to the nucleus, followed by the modulation of transcriptional and translational processes. The receptors that transmit these effects have been cloned and represent the superfamily of steroid receptors, including the classic intracellular MR [13].

Rapid non-genomic effects of aldosterone have been ascribed to undefined membrane receptors and intracellular signaling pathways. These kinds of aldosterone effects were not blocked by spironolactone, actinomycin D or cycloheximide, suggestive of the distinct mechanisms from the MR, and gene transcription and translation. In vascular smooth muscles and mononuclear leukocytes, aldosterone stimulated phosphoinositide hydrolysis and thus inositol 1,4,5 triphosphate $\left(\mathrm{IP}_{3}\right)$ and diacylglycerol (DAG) formation within minutes [20]. The increase in $\mathrm{IP}_{3}$-induced $\mathrm{Ca}^{2+}$ release from intracellular $\mathrm{Ca}^{2+}$ stores could explain the aldosterone-induced increase in $\left[\mathrm{Ca}^{2+}\right]_{\mathrm{i}}$ in these cell types. Aldosterone increased $\left[\mathrm{Ca}^{2+}\right]_{\mathrm{i}}$ and cAMP even in the mice skin cells where MR is knocked out [13]. These effects were not induced by micromolar concentrations of hydrocortisone or blocked by spironolactone. In human bronchial epithelial cells, aldosterone reduced $\left[\mathrm{Ca}^{2+}\right]_{\mathrm{i}}$ via a non-genomic mechanism, involving the activation of endoplasmic reticulum (ER) $\mathrm{Ca}^{2+}$-ATPase and adenyl cyclase- and PKA-coupled signaling pathways [14]. In human distal colon and in mouse cortical collecting duct, aldosterone increased $\left[\mathrm{Ca}^{2+}\right]_{\mathrm{i}}$ via protein kinase C (PKC) $[21$, 22].

In cardiac myocytes, molecular steps that mediate nongenomic effects of aldosterone remain unclear. Mihailidou et al. reported that aldosterone-induced activation of $\mathrm{NKCC} 1$ was mediated by $\varepsilon \mathrm{PKC}$ in rabbit ventricular myocytes [23]. Another report by Mano et al. suggested a specific plasma membrane receptor coupled with phospholipase C [24].

On the other hand, recent reports have indicated that the classical MR seems to participate at least in some rapid nongenomic effects of aldosterone, because MR blockers abolished them [25]. However, we and another study have shown that spironolactone could by itself modify intracellular ion concentrations and cell function independently of MR [26, 27]. Furthermore, under physiological conditions, MRs in cardiac myocytes are normally occupied by endogenous glucocorticoid because $11 \beta$-hydroxysteroid dehydrogenase is not usually expressed in cardiac myocytes and there are high levels of circulating cortisol [28]. Thus, at the present state, the specific membrane receptors for aldosterone are not yet cloned, and the involvement of MR remains undefined. Future studies are necessary to elucidate the receptorintracellular signaling pathways of the non-genomic effects of aldosterone.

\section{NON-GENOMIC EFFECTS OF ALDOSTERONE ON INTRACELLULAR ION REGULATION}

\section{(a) $\mathrm{Na}^{+}$}

Regarding non-genomic effects of aldosterone on $\left[\mathrm{Na}^{+}\right]_{\mathrm{i}}$, there have been several reports that showed a rapid rise in intracellular $\mathrm{Na}^{+}$activity in rabbit papillary muscles [29], and increases in $\left[\mathrm{Na}^{+}\right]_{\mathrm{i}}$ in rat ventricular myocytes under normal and high $\left[\mathrm{Na}^{+}\right]_{\text {o }}$ conditions $[26,30]$. These aldosterone-induced $\mathrm{Na}^{+}$increases were independent of the MR.

We examined the non-genomic effects of aldosterone on $\left[\mathrm{Na}^{+}\right]_{\mathrm{i}}$ in isolated rat ventricular myocytes using a laser scanning confocal microscopy and a $\mathrm{Na}^{+}$-sensitive fluorescent dye Sodium-green [27]. Aldosterone rapidly elevated $\left[\mathrm{Na}^{+}\right]_{\mathrm{i}}$ at the concentrations of $0.1 \mu \mathrm{M}$ to $10 \mu \mathrm{M}$ (Figs. 1A \& B). The aldosterone-induced increase in $\left[\mathrm{Na}^{+}\right]_{\mathrm{i}}$ was not abolished by the co-administration of actinomycin $\mathrm{D}$, an inhibitor of transcription. This data confirmed that aldosterone actually modified $\left[\mathrm{Na}^{+}\right]_{\mathrm{i}}$ by rapid non-genomic effects. The extent of the increase in $\left[\mathrm{Na}^{+}\right]_{\mathrm{i}}$ and the concentration of aldosterone varied among the studies (presumably from differences in animal species, specimens and temperature), but the increase was estimated to be 1 1.5 mM [24, 29-31].

The non-genomic effects of aldosterone on membrane $\mathrm{Na}^{+}$regulatory proteins have been observed in various cell types. In human mononuclear leukocytes and vascular smooth muscle cells, aldosterone activated $\mathrm{Na}^{+} / \mathrm{H}^{+}$exchange, resulting in intracellular alkalinization $[15,32]$. In vascular smooth muscle cells, the involvement of NKCC1 in aldosterone-induced changes in $\mathrm{Na}^{+}$flux was also described [11].

In cardiac myocytes, $\left[\mathrm{Na}^{+}\right]_{\mathrm{i}}$ is principally determined by the balance between $\mathrm{Na}^{+}$influxes via $\mathrm{Na}^{+} / \mathrm{H}^{+}$exchange and the fast $\mathrm{Na}^{+}$channel, and $\mathrm{Na}^{+}$extrusion by $\mathrm{Na}^{+} / \mathrm{K}^{+}$-ATPase. The $\mathrm{Na}^{+}$influx via NKCC1 seems to be less important [33, 34].

The aldosterone-induced increase in $\left[\mathrm{Na}^{+}\right]_{\mathrm{i}}$ was abolished by the inhibition of $\mathrm{Na}^{+} / \mathrm{H}^{+}$exchange or NKCC1 (Fig. 1D). These findings were also found in other studies [29, 30]. Mihailidou et al. demonstrated that the increased $\mathrm{Na}^{+}$influx by acute activation of $\mathrm{NKCC} 1$ stimulated $\mathrm{Na}^{+} / \mathrm{K}^{+}$pump current [29], but aldosterone directly inhibited $\mathrm{Na}^{+} / \mathrm{K}^{+}$-ATPase [31]. We confirmed that a rapid increase in $\left[\mathrm{Na}^{+}\right]_{\mathrm{i}}$ by aldosterone occurred even after the inhibition of $\mathrm{Na}^{+} / \mathrm{K}^{+}$-ATPase, and bumetanide prevented the aldosterone-induced increase in $\left[\mathrm{Na}^{+}\right]_{\mathrm{i}}$ [27]. Therefore, both $\mathrm{Na}^{+} / \mathrm{H}^{+}$exchange and NKCC1 are likely to contribute to the increase in $\left[\mathrm{Na}^{+}\right]_{\mathrm{i}}$ induced by a non-genomic effect of aldosterone, whereas the inhibition of $\mathrm{Na}^{+} / \mathrm{K}^{+}$-ATPase might also participate.

\section{(b) $\mathrm{Ca}^{2+}, \mathrm{Mg}^{2+}$}

Previous reports have shown that aldosterone increased $\left[\mathrm{Ca}^{2+}\right]_{\mathrm{i}}$ within $1 \mathrm{~h}$ in human mononuclear leukocytes, cultured skeletal muscle cells and porcine aortic endothelial cells $[16,35,36]$. In these tissues, the aldosterone-induced increase in $\left[\mathrm{Ca}^{2+}\right]_{\mathrm{i}}$ was thought to be mainly mediated by phosphoinositide hydrolysis. The production of $\mathrm{IP}_{3}$ caused a $\mathrm{Ca}^{2+}$ release from intracellular $\mathrm{IP}_{3}$-sensitive stores.

In adult cardiac myocytes, this mechanism seems to be rather small since $\mathrm{Ca}^{2+}$-induced $\mathrm{Ca}^{2+}$ release from the sarcoplasmic reticulum is more important for excitationcontraction coupling. Actually, there are no reports that showed the changes in $\mathrm{Ca}^{2+}$ transient by the non-genomic effects of aldosterone. It was demonstrated that aldosterone increased L-type $\mathrm{Ca}^{2+}$ currents as the genomic effect but did not change it within 24 hours [17]. We and another report 

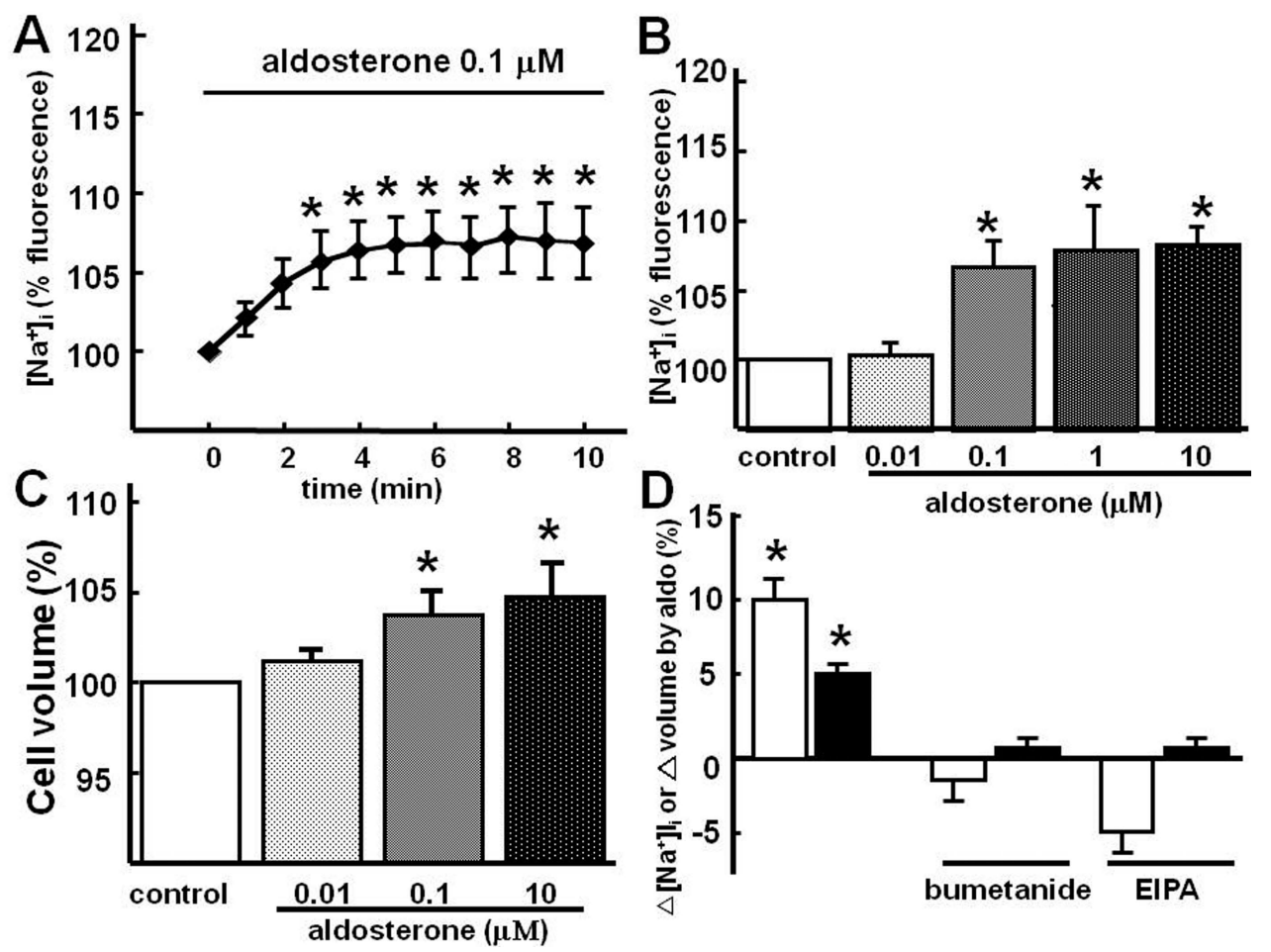

Fig. (1). Effects of aldosterone on $\left[\mathrm{Na}^{+}\right]_{\mathrm{i}}$ and cell volume.

(A) The time-dependent change in $\left[\mathrm{Na}^{+}\right]_{\mathrm{i}}$ during the perfusion of $0.1 \mu \mathrm{M}$ aldosterone.

(B) The concentration-dependent changes in $\left[\mathrm{Na}^{+}\right]_{\text {i. }}$ The changes in $\left[\mathrm{Na}^{+}\right]_{\mathrm{i}}$ were expressed as \% changes of fluorescence intensity of sodiumgreen. (C) The concentration-dependent change in cell volume. Cell volume was measured by 3-dimensional reconstruction from optical sections of a calcein-loaded myocyte.

(D) Changes in $\left[\mathrm{Na}^{+}\right]_{\mathrm{i}}$ (empty columns) and cell volume (filled columns) by aldosterone $(0.1 \mu \mathrm{M})$. The aldosterone-induced increases in $\left[\mathrm{Na}^{+}\right]_{\mathrm{i}}$ and cell volume were abolished by the preincubation of bumetanide (an inhibitor of NKCC1) or 5-(N-ethyl-N-isopropyl) amiloride (EIPA, an inhibitor of $\mathrm{Na}^{+} / \mathrm{H}^{+}$exchange). Data is shown as means $\pm \mathrm{SE}$ from $5-8$ experiments. $* \mathrm{p}<0.05 v s$. control by ANOVA. (Data is taken from Matsui et al. ref. 27).

also showed no immediate change in the profile of twitch $\mathrm{Ca}^{2+}$ transients in adult cardiac myocytes [26, 27]. Only one report exhibited a nifedipine-sensitive rapid increase in $\left[\mathrm{Ca}^{2+}\right]_{\mathrm{i}}$ in aldosterone-treated neonatal rat cardiac myocytes [24].

These findings, however, provoke the question why a significant increase in $\left[\mathrm{Na}^{+}\right]_{\mathrm{i}}$ due to the activation of $\mathrm{NKCC} 1$ and $\mathrm{Na}^{+} / \mathrm{H}^{+}$exchange does not augment $\mathrm{Ca}^{2+}$ transients. Under physiological conditions, the increase in $\left[\mathrm{Na}^{+}\right]_{\mathrm{i}}$ is expected to elevate $\left[\mathrm{Ca}^{2+}\right]_{\mathrm{i}}$ by decreasing $\mathrm{Ca}^{2+}$ efflux (or increasing $\mathrm{Ca}^{2+}$ influx) via $\mathrm{Na}^{+} / \mathrm{Ca}^{2+}$ exchange [34]. The possible explanations are that $(1)$ the increase in $\left[\mathrm{Na}^{+}\right]_{\mathrm{i}}$ by aldosterone was too small to affect $\mathrm{Ca}^{2+}$ regulation, (2) aldosterone increased cellular $\mathrm{Ca}^{2+}$ gain but the concomitant increase in cell volume minimized the increase in $\left[\mathrm{Ca}^{2+}\right]_{i}$, and (3) other unknown non-genomic pathways cancelled the effects of the increase in $\left[\mathrm{Na}^{+}\right]_{\mathrm{i}}$. Regarding the last possibility, we observed that aldosterone directly accelerated the $\mathrm{Na}^{+} / \mathrm{Ca}^{2+}$ exchange current in guinea pig ventricular myocytes (personal data).

$\mathrm{Mg}^{2+}$ is an abundant divalent intracellular cation and acts to regulate energy state and $\left[\mathrm{Ca}^{2+}\right]_{\mathrm{i}}$. Trans-membrane $\mathrm{Mg}^{2+}$ fluxes are linked to $\mathrm{Na}^{+}$-dependent $\mathrm{Mg}^{2+}$ exchange activity, but the detailed molecular mechanisms that regulate these fluxes are still unknown [37]. It has been reported that hy- peraldosteronism is associated with $\mathrm{Mg}^{2+}$ loss in urine. Although there is no study examining the effect of aldosterone on $\mathrm{Mg}^{2+}$ regulation in the heart, the changes in $\mathrm{Mg}^{2+}$ status may influence the intracellular $\mathrm{Ca}^{2+}$ regulation and cellular function.

(c) $\mathrm{H}^{+}$

The activation of $\mathrm{Na}^{+} / \mathrm{H}^{+}$exchange causes intracellular alkalinization because of $\mathrm{H}^{+}$extrusion. In fact, several reports have shown an aldosterone-induced rapid increase in $\mathrm{pH}_{\mathrm{i}}$ in a variety of tissues including the heart [26, 30, 38, 39]. The involvement of $\mathrm{Na}^{+} / \mathrm{H}^{+}$exchange was judged by the ability of amiloride derivatives to abolish the response. The increase in cytosolic $\mathrm{pH}_{\mathrm{i}}$ has important meaning because it causes not only positive inotropy (due to the leftward shift of pCa-ATPase curve of myofilaments), but also cardiac hypertrophy and remodeling as discussed below.

\section{PHYSIOLOGICAL AND PATHO-PHYSIOLO- GICAL IMPLICATION OF NON-GENOMIC EFFE- CTS OF ALDOSTERONE}

\section{(a) Cell Volume}

Aldosterone has been recognized as a key regulator of fluid and electrolyte balance in many organs including the kidney. The aldosterone-induced rapid increase in cell vol- 
ume was reported in human mononuclear leukocytes and also in neonatal rat cardiac myocytes $[30,40]$.

A recent report demonstrated that an acute exposure to elevated $\left[\mathrm{Na}^{+}\right]_{\mathrm{o}}$ caused rapid shrinkage of cardiac myocytes as a result of fluid loss, and aldosterone strongly suppressed it by increasing $\mathrm{Na}^{+}$entry into cardiac myocytes [30]. Thus, the principal effect of aldosterone is to maintain $\mathrm{Na}^{+}$homeostasis and to protect myocytes from osmotic stress. As shown in Fig. (1C), we also found that aldosterone increased cell volume in adult rat ventricular myocytes [27, 41]. Since the aldosterone-induced increase in cell volume was blocked by an amiloride derivative or bumetanide (Fig. 1D), the activation of $\mathrm{Na}^{+}$influxes was associated with the increase in cell volume [27, 42].

\section{(b) Contractility}

Aldosterone was initially found to decrease cardiac output within $5 \mathrm{~min}$, while peripheral vascular resistance and blood pressure increased [43]. More recently, aldosterone induced a negative inotropic response in human myocardial trabeculae [44]. On the other hand, in Langendorff-perfused and working rat hearts, aldosterone increased left ventricular developed pressure immediately $[45,46]$. Spironolactone and eplerenone did not block these positive and negative inotropic effects. Therefore, in vivo evidence of the nongenomic effect of aldosterone on cardiac contractility has not yet been confirmed, since the changes in coronary flow and peripheral vascular resistance also occurred.

As mentioned above, aldosterone did not change $\mathrm{Ca}^{2+}$ transients but increased $\mathrm{pH}_{\mathrm{i}}$. The non-genomic effect of al- dosterone appears to cause positive inotropy due to the leftward shift of the pCa-ATPase curve in myofilaments. In our previous study, however, the perfusion of aldosterone did not alter cell shortening in isolated rat myocytes, developed tension in rat papillary muscles, or left ventricular developed pressure in Langendorff-perfused rat hearts [27]. There seems to be species difference in contractile response to aldosterone, presumably due to the difference in response of $\mathrm{pH}_{\mathrm{i}}$. Actually, we found that aldosterone increased $\mathrm{pH}_{\mathrm{i}}$ in guinea pig ventricular myocytes but did not in rats (personal data).

\section{(c) Cardiac Hypertrophy, Fibrosis, and Remodeling}

Basic and clinical studies have shown that aldosteroneinduced cardiac hypertrophy, fibrosis and remodeling are suppressed by MR antagonists, suggesting the genomic effects of aldosterone [3, 4, 47, 48]. However, as mentioned above, the non-genomic effects of aldosterone involve the modulation of various membrane proteins that are associated with downstream hypertrophic signals (Fig. 2). In patients with hypertension or heart failure, local aldosterone levels are often elevated, and the aldosterone induces local expression of angiotensin-converting enzyme, creating a vicious cycle involving the renin-angiotensin-aldosterone system. Thus, the non-genomic effects of aldosterone, in concert with genomic effects, can have some patho-physiological relevance.

Actually, the aldosterone-induced activation of $\mathrm{Na}^{+} / \mathrm{H}^{+}$ exchange, $\mathrm{Ca}^{2+}$ overload, myocyte swelling, apoptosis, and the increase in matrix metalloproteinase (MMP) activity have been reported to contribute to cardiac hypertrophy and

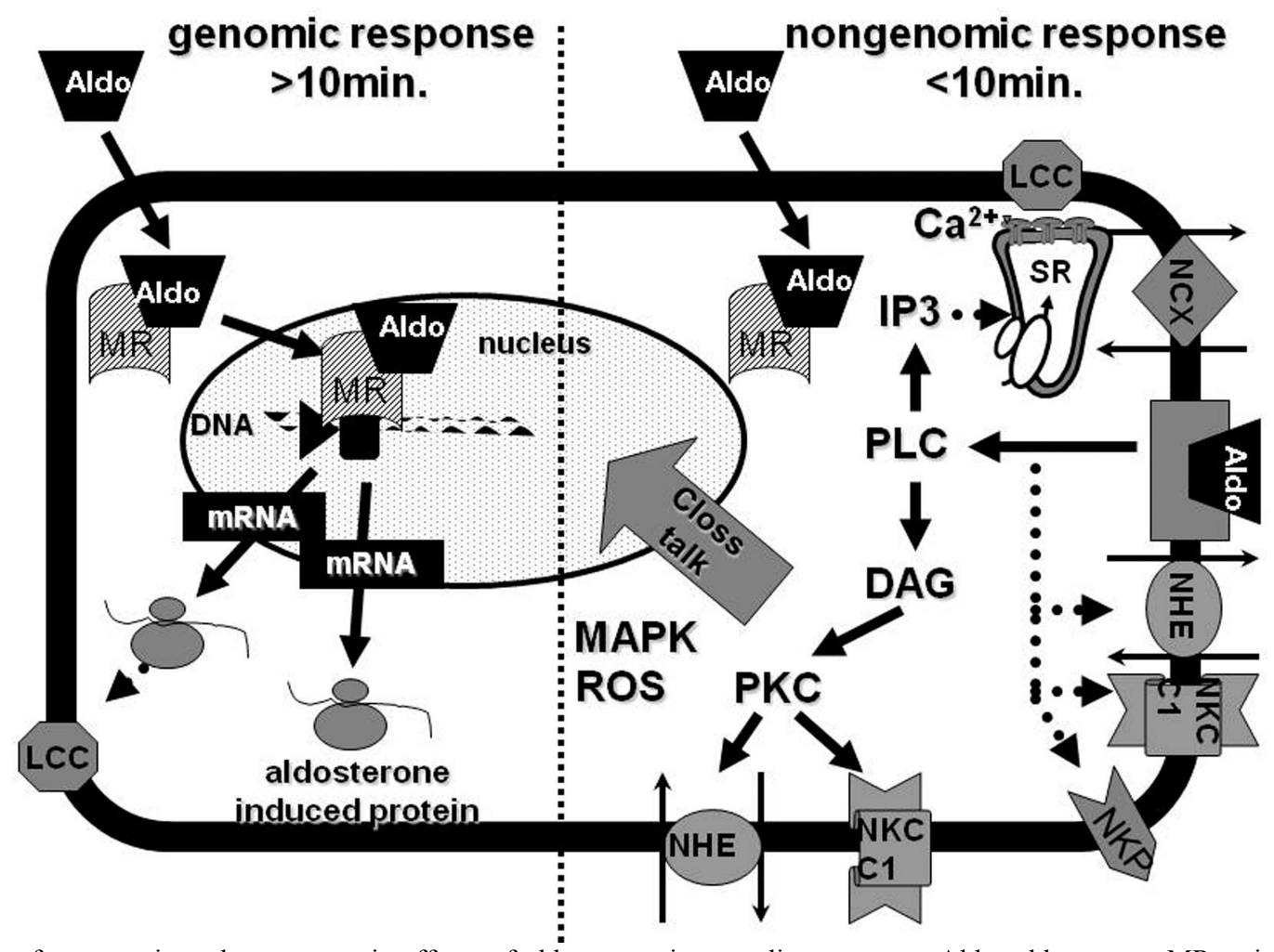

Fig. (2). A scheme for genomic and non-genomic effects of aldosterone in a cardiac myocyte. Aldo: aldosterone, MR: mineralocorticoid receptor, LCC: L-type $\mathrm{Ca}^{2+}$ channel, NHE: $\mathrm{Na}^{+} / \mathrm{H}^{+}$exchange, $\mathrm{NCX}: \mathrm{Na}^{+} / \mathrm{Ca}^{2+}$ exchange, NKCC1: $\mathrm{Na}^{+}-\mathrm{K}^{+}-2 \mathrm{Cl}^{-}$co-transporter, $\mathrm{NKP}: \mathrm{Na}^{+}-\mathrm{K}^{+}$ pump, SR: sarcoplasmic reticulum, ROS: reactive oxygen species. 
remodeling [24, 30, 49, 50]. Second messenger pathways that link these patho-physiological effects of aldosterone include PKC (especially its $\mathrm{Ca}^{2+}$-independent isoform, $\mathrm{PKC \varepsilon})$, mitogen/ extracellular signal-regulated kinase (MEK), extracellular signal-regulated kinase $1 / 2$ (ERK 1/2), and the generation of reactive oxygen species (ROS) [23, 24, 49]. It is reported that aldosterone rapidly increased generation of ROS by activating NADPH oxidase [49]. The increase in ROS generation can relate to myocyte damage, inflammation, and activation of MMP.

\section{CONCLUSIONS}

Aldosterone exerts several non-genomic effects on cellular ionic regulation and function in the heart (as well as in other tissues). The various non-genomic effects of aldosterone have been described during the past decades, but the identification, characterization, and cloning of the membrane receptor for them remain the major goals. The second messengers and the interaction with MR-dependent genomic actions also remain to be elucidated. The physiological and pathophysiological relevance of non-genomic effects of aldosterone should be further characterized, and the development of novel specific antagonists may yield therapeutic benefits for a variety of cardiovascular diseases.

\section{REFERENCES}

[1] Swedberg K, Eneroth P, Kjekshus J, Wilhelmsen L. Hormones regulating cardiovascular function in patients with severe congestive heart failure and their relation to mortality. CONSENSUS Trial Study Group. Circulation 1990; 83: 1730-6.

[2] Brown NJ. Eplerenone: cardiovascular protection. Circulation 2003; 107: 2512-8.

[3] Pitt B, Zannda F, Remme WJ, et al. The effect of spironolactone on morbidity and mortality in patients with severe heart failure. The Randomized Aldactone Evaluation Study Investigators . N Eng J Med 1999; 341: 709-17.

[4] Pitt B, Williams G, Remme W, et al. The EPHESUS trial: eplerenone in patients with heart failure due to systolic dysfunction complicating acute myocardial infarction. Eplerenone Post-AMI Heart Failure Efficacy and Survival Study. Cardiovasc Drugs Ther 2001; 15: 79-87.

[5] Rousseau MF, Gume O, Duprez D, et al. Beneficial neurohumoral profile of spironolactone in severe congestive heart failure: results from the RALES neurohumoral substudy. J Am Coll Cardiol 2002; 40: 1596-601.

[6] Silvestre JS, Robert V, Heymes C, et al. Myocardial production of aldosterone and corticosterone in the rat. J Biol Chem 1998; 273: 4883-91.

[7] Funder JW. Aldosterone action: fact, failure and the future. Clin Exp Pharmacol Physiol Suppl 1998; 25: S47-S50.

[8] Wehling M, Scriba PC. Non-genomic aldosterone action. A new concept for the mechanism of action of steroids is developed. Internist (Berl) 1995; 36: 338-42.

[9] Spach C, Streeten DH. Retardation of sodium exchange in dog erythrocytes by physiological concentrations of aldosterone in vitro. J Clin Invest 1964; 43: 217-27.

[10] Liu SL, Schmuck S, Chorazcyzewski JZ, Gros R, Feldman RD. Aldosterone regulates vascular reactivity: short-term effects mediated by phosphatidylinositol 3-kinase-dependent nitric oxide synthase activation. Circulation 2003; 108: 2400-6.

[11] Jiang G, Cobbs S, Klein JD, O'Neill WC. Aldosterone regulates the $\mathrm{Na}-\mathrm{K}-2 \mathrm{Cl}$ cotransporter in vascular smooth muscle. Hypertension 2003; 41: 1131-5.

[12] Koppel H, Christ M, Yard BA, Bar PC, van der Woude FJ, Wehling M. Nongenomic effects of aldosterone on human renal cells. $\mathrm{J}$ Clin Endocrinol Metab 2003; 88: 1297-302.
[13] Haseroth K, Gerdes D, Bergerb S, et al. Rapid nongenomic effects of aldosterone in mineralocorticoid-receptor-knockout mice. Biochem Biophys Res Commun 1999; 266: 257-61.

[14] Urbach V, Harvey BJ. Rapid and non-genomic reduction of intracellular $\left[\mathrm{Ca}^{2+}\right]$ induced by aldosterone in human bronchial epithelium. J Physiol 2001; 537: 267-75.

[15] Wehling M, Armanini D, Strasser T, Weber PC. Effect of aldosterone on sodium and potassium concentrations in human mononuclear leukocytes. Am J Physiol 1987; 252: E505-8.

[16] Estrada M, Liberona JL, Miranda M, Jaimovich E. Aldosteroneand testosterone-mediated intracellular calcium response in skeletal muscle cell cultures. Am J Physiol Endocrinol Metab 2000; 279: E132-9.

[17] Benitah JP, Vassort G. Aldosterone upregulates $\mathrm{Ca}^{2+}$ current in adult rat cardiomyocytes. Circ Res 1999; 85: 1139-45.

[18] Benitah JP, Perrier E, Gomez AM, Vassort G. Effects of aldosterone on transient outward $\mathrm{K}^{+}$current density in rat ventricular myocytes. J Physiol 2001; 537: 151-60.

[19] Karmazyn M, Liu Q, Gan XT, Brix BJ, Fliegel L. Aldosterone increases NHE-1 expression and induces NHE-1-dependent hypertrophy in neonatal rat ventricular myocytes. Hypertension 2003; 42: 1171-6.

[20] Christ M, Eisen C, Aktas J, Theisen K, Wehling M. The inositol$1,4,5$-trisphosphate system is involved in rapid effects of aldosterone in human mononuclear leukocytes. J Clin Endocrinol Metab 1993; 77: 1452-7.

[21] Doolan CM, Harvey BJ. Modulation of cytosolic protein kinase C and calcium ion activity by steroid hormones in rat distal colon. $\mathrm{J}$ Biol Chem 1996; 271: 8763-7.

[22] Harvey BJ, Higgins M. Nongenomic effects of aldosterone on $\mathrm{Ca}^{2+}$ in M-1 cortical collecting duct cells. Kidney Int 2000; 57: 1395403.

[23] Mihailidou AS, Mardini M, Funder JW. Rapid, nongenomic effects of aldosterone in the heart mediated by epsilon protein kinase $\mathrm{C}$. Endocrinology 2004; 145: 773-80.

[24] Mano A, Tatsumi T, Shiraishi J, et al. Aldosterone directly induces myocyte apoptosis through calcineurin-dependent pathways. Circulation 2004; 110: 317-23.

[25] Funder JW. Non-genomic actions of aldosterone: role in hypertension. Curr Opin Nephrol Hypertens 2001; 10: 227-30.

[26] Barbato JC, Rashid S, Mulrow PJ, Shapiro JI, Franco-Saenz R. Mechanisms for aldosterone and spironolactone-induced positive inotropic actions in the rat heart. Hypertension 2004; 44: 751-7.

[27] Matsui S, Satoh H, Kawashima H, et al. Non-genomic effects of aldosterone on intracellular ion regulation and cell volume in rat ventricular myocytes. Can J Physiol Pharmacol 2007; 85: 264-73.

[28] Young MJ, Funder JW. Mineralocorticoid receptors and pathophysiological roles for aldosterone in the cardiovascular system. J Hypertens 2002; 20: 1465-8.

[29] Mihailidou AS, Buhagiar K A, Rasmussen $\mathrm{HH} . \mathrm{Na}^{+}$influx and $\mathrm{Na}^{+}-\mathrm{K}^{+}$pump activation during short-term exposure of cardiac myocytes to aldosterone. Am J Physiol 1998; 274: C175-81.

[30] Yamamuro M, Yoshimura M, Nakayama M, et al. Direct effects of aldosterone on cardiomyocytes in the presence of normal and elevated extracellular sodium. Endocrinology 2006; 147: 1314-21.

[31] Mihailidou AS, Bundgaard H, Mardini M, Hansen PS, Kjeldsen K, Rasmussen HH. Hyperaldosteronemia in rabbits inhibits the cardiac sarcolemmal $\mathrm{Na}^{+}-\mathrm{K}^{+}$pump. Circ Res 2000; 86: 37-42.

[32] Christ M, Douwes K, Eisen C, Bechtner G, Theisen K, Wehling M. Rapid effects of aldosterone on sodium transport in vascular smooth muscle cells. Hypertension 1995; 25: 117-23.

[33] Katoh H, Satoh H, Nakamura T, Terada H, Hayashi H. The role of $\mathrm{Na}^{+} / \mathrm{H}^{+}$exchange and the $\mathrm{Na}^{+} / \mathrm{K}^{+}$pump in the regulation of $\left[\mathrm{Na}^{+}\right]_{i}$ during metabolic inhibition in guinea pig myocytes. Biochem Biophys Res Commun 1994; 203: 93-8.

[34] Satoh H, Hayashi H, Noda N, et al. Regulation of $\left[\mathrm{Na}^{+}\right]_{\mathrm{i}}$ and $\left[\mathrm{Ca}^{2+}\right]$ in guinea pig myocytes: dual loading of fluorescent indicators SBFI and fluo 3. Am J Physiol 1994; 266: H568-76.

[35] Wehling M, Kasmayr J, Theisen K. Aldosterone influences free intracellular calcium in human mononuclear leukocytes in vitro. Cell Calcium 1990; 11: 565-71.

[36] Schneider M, Ulsenheimer A, Christ M, Wehling M. Nongenomic effects of aldosterone on intracellular calcium in porcine endothelial cells. Am J Physiol 1997; 272: E616-20.

[37] Touyz RM, Schiffrin EL. Angiotensin II and vasopressin modulate intracellular free magnesium in vascular smooth muscle cells 
through $\mathrm{Na}^{+}$-dependent protein kinase $\mathrm{C}$ pathways. J Biol Chem 1996; 271: 24353-8.

[38] Winter DC, Schneider MF, O'Sullivan GC, Harvey BJ, Geibel JP. Rapid effects of aldosterone on sodium-hydrogen exchange in isolated colonic crypt. J Membr Biol 1999; 170:17-26.

[39] Wehling M, Bauer MM, Ulsenheimer A, Schneider M, Neylon CB, Christ M. Nongenomic effects of aldosterone on intracellular $\mathrm{pH}$ in vascular smooth muscle cells. Biophys Biochem Res Commun 1996; 223: 181-6.

[40] Wehling M, Kuhls S, Armanini D. Volume regulation of human lymphocytes by aldosterone in isotonic media. Am J Physiol 1989; 257: E170-4.

[41] Satoh H, Delbridge LM, Blatter LA, Bers DM. Surface:volume relationship in cardiac myocytes studied with confocal microscopy and membrane capacitance measurements: species-dependence and developmental effects. Biophys J 1996; 70: 1494-504.

[42] Askenasy N, Vivi A, Tassini M, Navon G. Cardiac energetics, cell volumes, sodium fluxes, and membrane permeability: NMR studies of cold ischemia. Am J Physiol 1995; 269: H1056-64.

[43] Klein K, Henk W. Klinish-experimentelle untersuchungen über den ein-fluss von aldosteron and hamodynamik und gerinnung. Z Kreisl Forsch 1963; 52:40-53.
[44] Chai W, Garrelds IM, de Vries R, Batenburg WW, van Kats JP, Jan Danser AH. Nongenomic effects of aldosterone in the human heart interaction with angiotensin II. Hypertension 2005; 46: 701-6.

[45] Chai W, Garrelds IM, Arulmani U, Schoemaker RG, Lamers JMJ, Danser AHJ. Genomic and non-genomic effects of aldosterone in the rat heart: why is spironolactone cardioprotective? $\mathrm{Br} \mathrm{J}$ Pharmacol 2005; 145: 664-71.

[46] Barbato JC, Mulrow PJ, Shapiro JI, Franco-Saenz R. Rapid effects of aldosterone and spironolactone in the isolated working rat heart. Hypertension 2002; 40: 130-5.

[47] Brilla CG, Matsubara LS, Weber KT. Antifibrotic effects of spironolactone in preventing myocardial fibrosis in systemic arterial hypertension. Am J Cardiol 1993; 71: 12A-16A.

[48] Young MJ, Funder JW. The renin-angiotensin-aldosterone system in experimental mineralocorticoid-salt-induced cardiac fibrosis. Am J Physiol 1996; 271: E883-8.

[49] Rude MK, Duhaney TS, Kuster GM, et al. Aldosterone stimulates matrix metalloproteinases and reactive oxygen species in adult rat ventricular cardiomyocytes. Hypertension 2004; 46: 555-61.

[50] Wang GL, Wang GX, Yamamoto S, et al. Molecular mechanisms of regulation of fast-inactivating voltage-dependent transient outward $\mathrm{K}^{+}$current in mouse heart by cell volume changes. J Physiol 2005; 568: 423-43.

(C) Satoh et al.; Licensee Bentham Open.

This is an open access article licensed under the terms of the Creative Commons Attribution Non-Commercial License (http://creativecommons.org/licenses/by-nc/3.0/) which permits unrestricted, non-commercial use, distribution and reproduction in any medium, provided the work is properly cited. 